\title{
Congenital Aortic Arch Hypoplasia
}

National Cancer Institute

\section{Source}

National Cancer Institute. Congenital Aortic Arch Hypoplasia. NCI Thesaurus. Code C103266.

An underdeveloped aortic arch that is present at birth. This symptom is usually found in association with other cardiac defects that characterize left heart syndrome. 